\title{
Analysis of the Dynamics of Structural Processes in the Context of Ensuring Sustainable Development
}

\author{
By Lilia Simkiv ${ }^{1}$, Svitlana Shults ${ }^{2}$, Olena Lutskiv ${ }^{2}$, Uliana Andrusiv ${ }^{1}$
}

\begin{abstract}
The tendencies and the extent of structural changes in the economy of the regions of Ukraine in the context of ensuring its sustainable development are examined in the context of the types of economic activity in terms of gross value added (GVA) during 2011-2018. In particular, the rate of change in the share of the structural mass of the economy of the regions that occurred during this period is estimated; the dynamic processes that took place in the structure of the economy of Ukrainian regions are analyzed. The analysis of the mass of structural changes shows their insignificant scale and reduction of the share in the structure of gross value added of such types of economic activity as industry, construction and finance. The estimation of intensity of structural changes by an indicator of average rates of their change shows low and rather differentiated level of intensity of structural changes in the context of types of economic activity. During the analyzed period, the annual average rate of structural changes in Ukraine was 0.131 . Based on the calculation of the rate of structural changes, it is proved that structural changes in the economy of Ukraine are quite slow and are characterized by significant interregional differentiation, and the lack of positive dynamics in increasing the speed of structural changes in education is the main obstacle to creating an innovationoriented model of economic development and reorientation of the structure of the regional economy to the requirements of the post-industrial type to the established concepts and dominants of sustainable development in accordance with EU standards.
\end{abstract}

Keywords: structure of economy, sustainable development, sphere of economic activity, mass of structural changes, rates of structural changes, speed of structural changes, intensity of economic processes, innovation activity.

\section{Introduction}

The experience of developed countries shows that the implementation of the priorities of the model of sustainable economic growth is accompanied by progressive structural changes in their economies. These structural changes, in accordance with the priorities of this model of sustainable development, should promote the productive use of resources, the development of environmentally friendly economic activities and intensify the process of technological and innovative restructuring of the economy as a whole. It should be recognized that the issue of resource conservation plays perhaps the most important role in understanding the prospects for development of the world community as a whole and individual countries, regions, cities and small territorial communities in terms of area and population.

As the experience of developed countries shows, high-quality economic growth should be accompanied by the accumulation of capital and structural changes in the economy that

| ${ }^{1}$ Ivano-Frankivsk National Technical University of Oil and Gas, 15, Carpathian str., Ivano-Frankivsk, 76018, Ukraine

2SI "Institute of Regional Research named after M.I. Dolishniy of the NAS of Ukraine, 4, Kozelnytska str., Lviv, 79026, Ukraine 
are consistent with global trends. Today in the country's economy there is only an increase in quantitative indicators of economic dynamics, which is explained by the attraction of additional resources or changes in market conditions. These negative trends are evidence of the absence of significant innovative and technological transformations in Ukraine. At the same time, it should be noted that we are not talking about the formation of a qualitative basis for reforms at all. The economic growth that is characteristic at the present stage, as a rule, is unstable and does not have a significant impact on improving the efficiency of the functioning of the regional economies, and, consequently, on increasing the level and quality of life of the population.

\section{Literature Review}

Structural changes should take place in the direction of reorienting the economy from the existing industrial and technological structure to the post-industrial one, in which the latest technologies and knowledge should be priority and determining factors of economic growth (Herrendorf, Rogerson, \& Valentinyi, 2014). Saleem et al., (2019) and Popadynets et al., (2020) emphasize that it is the structural transformation of the economy that serves as the basis for achieving a new quality of economic growth in terms of an innovative development model associated with the rapid development of the information and communication environment, scientific knowledge, and the introduction of advanced technologies (Saleem et al., 2019). The patterns between economic growth and structural changes in the economy have been studied by Yadav \& Joseph, (2018).

The work of Ikpe (2018) is also devoted to the study of structural changes in the economy. In his work he pays considerable attention to the study of the essence of transformation processes and assessment of the specific structure of the economy. The problems of structural changes in the economy, including the structure of industrial production are touched upon in the work of Zhao et al. (2012).

The consideration of qualitative parameters in the process of structural transformations implemented on the basis of modernization of the country's economic potential and innovation is the subject of research by Dyatlov et al. (2018) and Rohozian et al. (2020). In addition, a number of authors emphasize that structural adjustment requires a transition of the economy to a qualitatively different level of industrial development based on the introduction of the concept of smart specialization (Benner, 2019; Kroll, 2019; D'Adda, Guzzini, Iacobucci and Palloni, 2019; Sotarauta, 2018).

Gnangnon, (2020) in his work conducted a comparative analysis of structural changes in production in 81 countries. The results showed that the best results are in the countries that have adopted the CAF development strategy. Almeida, \& Balanco, (2020) argue that structural changes in the US economy did not occur suddenly, but were planned. Khan (2020) views export-oriented structural transformation as a panacea for economic development. In the paper by Cravino, \& Sotelo, (2019) it is proved that international trade has a significant impact on the employment and relative wages of unskilled workers when goods and services are traded at different intensities. Andrusiv et al. (2020) argue that innovation contributes to structural changes and economic development of regions. Ievdokymov et. al. (2020) and Ivashkiv et. al. (2020) in their study proved that structural change should be viewed through the prism of social capital, as it is a limited real or 
potential resource of social interaction. Research (Andrusiv \& Galtsova, 2017; Rohozian et al., 2017; Kramarenko et al., 2020) suggests ways to intensify the innovative activities of the Ukrainian economy, which will contribute to structural changes in the economy.

An important scientific task of modern research is to improve existing methodological approaches to assessing the trends, dynamics, quality and intensity of structural changes. In particular, in the work of Bogachkova et al. (2019) a technique was proposed that allows one to assess the volume and structure of GMP, as well as determine the direction of structural changes in the regional economy. Based on the calculations, the authors (Kneysler, et al., 2020; Zablodska et al., 2020) conclude that certain structural changes actually contribute to reducing the energy intensity of the economy of the regions, regardless of the implemented energy efficiency policy measures. Treshchevsky et al. (2018) based on the method of cluster analysis determined the interdependence of production, investment and employment in the context of their impact on the activityspecific structure of the regional economy. The obtained results allowed to propose promising areas of structural change in the economic and social spheres for each group of municipalities. Assessment of trends, dynamics and intensity of structural changes will allow to make the right management decisions to address the problem of overcoming the irrationality of the structure of the regional economy.

The aim of the paper is to analyze the trends, dynamics, scale and intensity of structural changes in terms of sustainable development in the regions of Ukraine in the context of the types of economic activity in terms of gross value added during 2011-2018.

\section{Results and Discussion}

The economy of the regions of Ukraine is characterized by certain changes in its quantitative parameters under the influence of market mechanisms and mechanisms of state regulation. The current state of the economy is a consequence of the negative processes that took place in the past. Therefore, it requires the implementation of structural changes in accordance with the well-established concepts and dominants of sustainable development in the future. The intensity of such changes will affect the socioeconomic development of the regions. Features of the dynamics and scale of structural changes are demonstrated by indicators of mass, rate, speed and intensity of structural changes.

The mass of the structural change is calculated by the formula:

$$
M=P_{1}-P_{0}
$$

where $P_{1}$ is the value in the current period, $\%$;

$P_{0}$ is the value in the reference period, $\%$.

The calculations show that during 2011-2018 in the Ukrainian economy, such types of economic activities as industry, construction and finance decreased rapidly. It should be noted that all regions of Ukraine are characterized by a decrease in the mass of structural changes in industry. The most significant reductions of the share of industry in the structure of the regional economy were observed in Khmelnytskyi (24.7\%), Sumy (15.7\%), Zaporizhzhia (10.9\%) and Ivano-Frankivsk (9.1) regions (Table 1). In other regions, the scale of structural changes, that is, changes in dynamics, is below the average for Ukraine. 
The lowest rates were recorded in the Kirovohrad region (3.3\%). This indicates the absence of significant changes in the share of industry in the structure of gross value added and the preservation of the structure-forming positions of industry in these regions.

Table 1. Mass of structural changes in the regions of Ukraine in 20011-2018, (\%)*

\begin{tabular}{|l|c|c|c|c|c|}
\hline Regions & $\begin{array}{c}\text { Agriculture, } \\
\text { forestry and } \\
\text { fisheries }\end{array}$ & Industry & Construction & $\begin{array}{c}\text { Wholesale and retail } \\
\text { trade and repair of motor } \\
\text { vehicles and motorcycles }\end{array}$ & $\begin{array}{c}\text { Transport, } \\
\text { warehousing, postal } \\
\text { and courier activities }\end{array}$ \\
\hline Ukraine & 1,5 & $-8,1$ & $-1,5$ & 2,4 & 0,4 \\
\hline Vinnytsia & 3,5 & $-7,2$ & -2 & 0,2 & $-2,3$ \\
\hline Volyn & $-0,7$ & $-4,3$ & $-3,5$ & $-2,9$ & $-0,4$ \\
\hline Donetsk & 1,3 & $-6,7$ & $-1,1$ & 1,9 & 1,6 \\
\hline Dnipropetrovsk & 0,8 & $-3,8$ & -1 & 6,6 & 0,3 \\
\hline Zhytomyr & 1,1 & $-3,9$ & $-1,6$ & $-1,8$ & $-2,4$ \\
\hline Zakarpattia & -1 & $-5,5$ & $-2,6$ & 0,2 & -2 \\
\hline Zaporizhzhia & 4,1 & $-10,9$ & $-1,3$ & 4,2 & 0 \\
\hline Ivano-Frankivsk & $-0,5$ & $-9,1$ & 1,3 & 4,8 & $-3,8$ \\
\hline Kyiv & $-1,6$ & $-8,9$ & $-1,9$ & 11,6 & 1,2 \\
\hline Kirovohrad & 5,3 & $-3,3$ & $-3,7$ & 2,7 & $-3,5$ \\
\hline Luhansk & 0,8 & $-3,1$ & $-1,5$ & 1,9 & 0,2 \\
\hline Lviv & -3 & $-5,1$ & $-2,5$ & 6,2 & $-0,5$ \\
\hline Mykolaiv & 7,5 & $-6,8$ & $-3,3$ & $-1,4$ & $-0,3$ \\
\hline Odesa & 1,7 & $-4,2$ & $-2,2$ & 5,1 & $-4,3$ \\
\hline Poltava & 5,6 & $-6,9$ & $-1,3$ & $-1,7$ & 0,2 \\
\hline Rivne & 1,2 & $-5,7$ & $-1,7$ & $-2,5$ & $-0,9$ \\
\hline Sumy & 3,4 & $-15,7$ & $-2,1$ & 9,8 & $-1,3$ \\
\hline Ternopil & 2,4 & $-5,6$ & $-2,3$ & $-1,4$ & $-2,8$ \\
\hline Kharkiv & 3,1 & -5 & $-2,2$ & 3,7 & 0,2 \\
\hline Kherson & 6,9 & $-6,2$ & -2 & $-2,5$ & $-2,7$ \\
\hline Khmelnytskyi & 5,8 & $-24,7$ & $-2,4$ & $-0,7$ & $-3,2$ \\
\hline Cherkasy & 2,9 & $-5,7$ & $-3,5$ & $-1,6$ & $-0,7$ \\
\hline Chernivtsi & 0,5 & $-6,8$ & $-2,8$ & $-4,3$ & $-1,2$ \\
\hline Chernihiv & 3 & -6 & $-2,8$ & 1 & 1,9 \\
\hline city of Kyiv & 0 & $-3,9$ & -1 & $-4,3$ & -3 \\
\hline (excly & 0 & -3 & 0 \\
\hline
\end{tabular}

* (excluding the temporarily occupied territory of the Autonomous Republic of Crimea, the city of Sevastopol and part of the anti-terrorist operation zone)

Table 1. Mass of structural changes in the regions of Ukraine in 20011-2018, (\%)* (continued)

\begin{tabular}{|l|c|c|c|c|c|c|}
\hline Regions & $\begin{array}{c}\text { Financial } \\
\text { activity }\end{array}$ & $\begin{array}{c}\text { Real estate } \\
\text { transactions }\end{array}$ & $\begin{array}{c}\text { Public } \\
\text { administration }\end{array}$ & Education & $\begin{array}{c}\text { Health care } \\
\text { and social } \\
\text { assistance }\end{array}$ & $\begin{array}{c}\text { Provision of utilities } \\
\text { and individual } \\
\text { services; activities in } \\
\text { the field of culture } \\
\text { and sports }\end{array}$ \\
\hline Ukraine & $-0,2$ & 4,4 & 0,1 & 0,7 & 0,3 & 0 \\
\hline Vinnytsia & $-0,7$ & 6 & 1 & 1,1 & 0,3 & 0,1 \\
\hline Volyn & 0,5 & 8,1 & 0,7 & 2,1 & 0,2 & 0,2 \\
\hline Donetsk & -2 & 2,1 & 1 & 0,8 & 0,7 & 0,4 \\
\hline Dnipropetrovsk & $-3,2$ & 0 & 0,3 & 0,3 & 0,1 & $-0,4$ \\
\hline Zhytomyr & 0,4 & 6,2 & 1,5 & 0,7 & 0,1 & $-0,3$ \\
\hline Zakarpattia & 0 & 6,7 & 1,2 & 2,1 & 1,1 & $-0,2$ \\
\hline Zaporizhzhia & -4 & 3,8 & 1,5 & 1,3 & 1,1 & 0,2 \\
\hline Ivano-Frankivsk & $-2,3$ & 7,4 & 1,5 & 0 & 0,5 & 0,2 \\
\hline
\end{tabular}




\begin{tabular}{|l|c|c|c|c|c|c|}
\hline Regions & $\begin{array}{c}\text { Financial } \\
\text { activity }\end{array}$ & $\begin{array}{c}\text { Real estate } \\
\text { transactions }\end{array}$ & $\begin{array}{c}\text { Public } \\
\text { administration }\end{array}$ & Education & $\begin{array}{c}\text { Health care } \\
\text { and social } \\
\text { assistance }\end{array}$ & $\begin{array}{c}\text { Provision of utilities } \\
\text { and individual } \\
\text { services; activities in } \\
\text { the field of culture } \\
\text { and sports }\end{array}$ \\
\hline Kyiv & $-1,8$ & 6,4 & $-3,4$ & $-0,7$ & $-0,4$ & $-0,5$ \\
\hline Kirovohrad & -1 & 3,5 & 0,2 & $-0,2$ & 0 & 0 \\
\hline Luhansk & $-1,1$ & 1,1 & 0,4 & 1,1 & 0,6 & $-0,2$ \\
\hline Lviv & $-0,2$ & 4,6 & 0,2 & 1 & $-0,3$ & $-0,4$ \\
\hline Mykolaiv & -2 & 3,9 & 1 & 1 & 0,1 & 0,3 \\
\hline Odesa & $-2,7$ & 4,3 & 0,6 & 1,3 & 0,4 & 0 \\
\hline Poltava & $-0,7$ & 4 & 0,5 & 0,2 & 0,2 & $-0,1$ \\
\hline Rivne & $-0,6$ & 5,8 & 1,8 & 1,1 & 1,2 & 0,3 \\
\hline Sumy & 0,8 & 3,8 & 0,5 & 0,7 & 0,3 & $-0,1$ \\
\hline Ternopil & 0,6 & 7,7 & 0,6 & 0,2 & 0,4 & 0,2 \\
\hline Kharkiv & $-7,5$ & 4,2 & $-0,1$ & 2,7 & 0,6 & 0,3 \\
\hline Kherson & 0,1 & 4,9 & 0,6 & 1 & 0 & 0 \\
\hline Khmelnytskyi & 0,1 & 6,4 & 1 & 2,6 & 0,6 & $-0,3$ \\
\hline Cherkasy & $-0,1$ & 4,7 & 0,2 & 0,6 & 0 & $-0,3$ \\
\hline Chernivtsi & $-0,4$ & 8,7 & 3 & 1,4 & 1,3 & 0,6 \\
\hline Chernihiv & -1 & 6,2 & 1,4 & 1 & 0 & 0,2 \\
\hline city of Kyiv & 6,7 & 3,7 & $-2,4$ & $-0,1$ & $-0,1$ & $-0,5$ \\
\hline
\end{tabular}

* (excluding the temporarily occupied territory of the Autonomous Republic of Crimea, the city of Sevastopol and part of the anti-terrorist operation zone)

A decrease in the mass of structural changes in construction in 2011-2018 took place in practically most regions of Ukraine, except for Ivano-Frankivsk region. This is a negative trend, since in most countries of the world the share of this type of economic activity, on the contrary, is growing. The reasons for this reduction are the following:

- deterioration of the conditions for financing construction enterprises (reduction in lending and increase in interest rates, the establishment of more stringent conditions for obtaining loans) due to the liquidity crisis in the Ukrainian financial market;

- a decrease in the effective demand of the corporate sector (due to a decrease in the volume of profits of enterprises and low availability of loans)

- a decrease in the effective demand of the population (due to a decrease in the real income of the population and the volume of mortgage lending).

A positive trend for the Ukrainian economy is the growth of the mass of structural shifts in the transactional sectors of the economy. The financial sector is an exception. In 2018, compared to 2011, the mass of structural changes in the financial sector decreased by $0.2 \%$. It should be noted that the financial sector is one of the most important sectors of the European economy and is gaining the greatest weight in the structure of their gross value added. However, in most regions of Ukraine there was a decrease in the structural mass of financial services. Volyn, Zhytomyr, Zakarpattia, Sumy, Ternopil, Kherson, Khmelnytskyi regions and city of Kiev were the exception.

An increase in the share of trade in the structure of the GVA was observed in 16 regions of the country. These shifts were most intense in the Kiev (11.6\%) and Sumy $(9.8 \%)$ regions. The lowest this indicator was in Vinnytsia and Zakarpattia regions $(0.2 \%)$. But a significant decrease in the structural mass of trade during 2011-2018 occurred in the 
Chernivtsi region and the city of Kiev (4.3\%).

The negative trends in the field of structural changes in the economy of Ukraine include a slight increase in the structure of GVA of the share of innovation-oriented economic activities. Thus, the increase in the share of education in the structure of the country's economy during 2011-2018 was insignificant and reached only 0.7\%. Along with this, its structural share decreased in 3 regions: Kyiv, Kirovohrad regions and city of Kyiv. Only in 4 regions of Ukraine, namely in Volyn, Zakarpattia, Kharkiv and Khmelnytskyi regions, the growth rate of the mass of structural changes in education significantly exceeded the average value in Ukraine, namely 3 times (in the first two regions), 3.8 times, 3 , 7 times respectively.

To study the dynamics of structural changes over time, the average rate and speed of structural changes are calculated. The average rate of structural changes reflects the trends of structural changes per unit time and is calculated by the formula:

$V=\frac{\left(P_{1} / P_{0}\right)}{T}$

where $T$ is the time during which the structural change occurred.

Assessing the intensity of structural changes in terms of the average rate of change, it should be noted that structural changes in the economy of Ukraine are quite slow. During the period 2011-2018, the annual average rate of structural changes in Ukraine was 0.111 per year (Fig. 1).

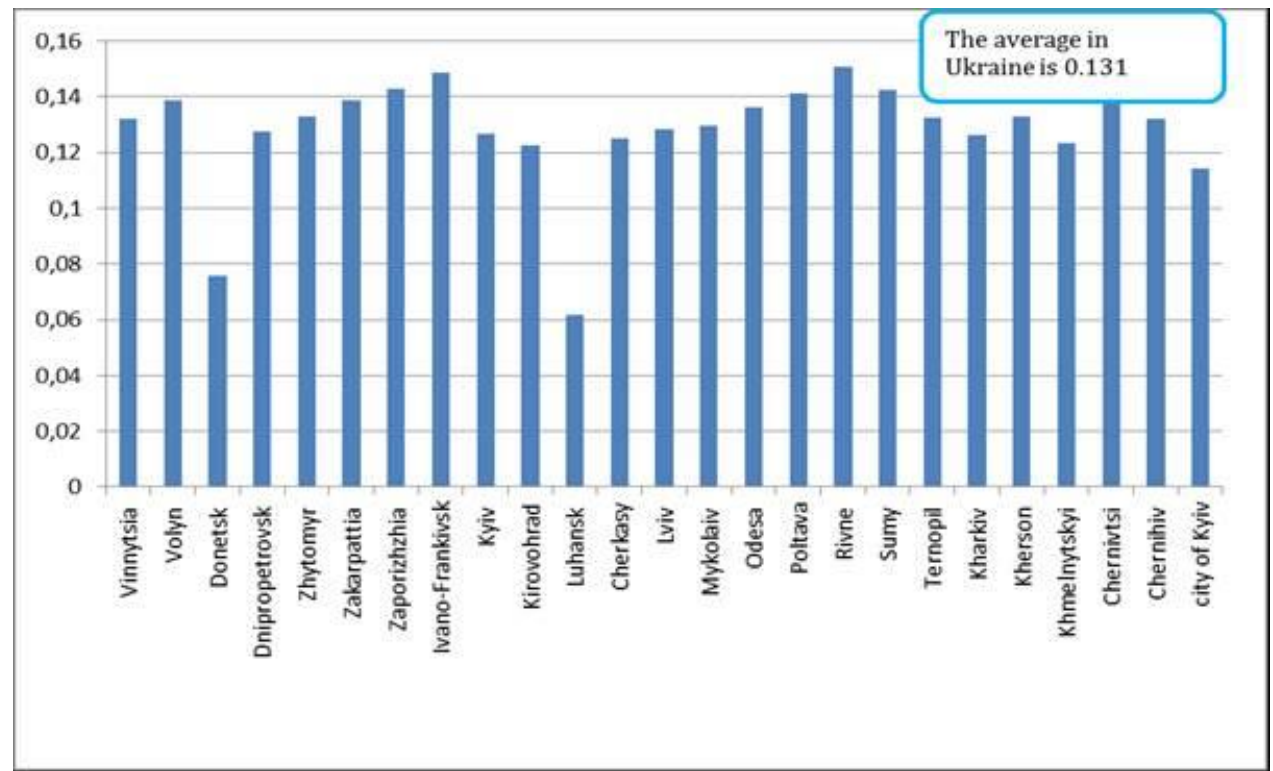

Figure 1. Average annual rates of structural changes in the regions of Ukraine in 2011-2018. * (excluding the temporarily occupied territory of the Autonomous Republic of Crimea, the city of Sevastopol and part of the antiterrorist operation zone)

During 2011-2018, the highest rates of structural changes occurred in Sumy (0.151), IvanoFrankivsk (0.149), Zaporizhzhia (0.143), Ternopil (0.142), Rivne (0.141) and Chernivtsi 
(0.141) regions. The lowest average annual rates of structural changes were recorded in Donetsk (0.076), Luhansk regions (0.062), city of Kyiv (0.114), as well as Kirovohrad and Cherkasy (0.123), Lviv (0.125) Kherson (0.127) regions, which is evidence of minor changes in the structure of their economies (Table 2).

Table 2. Average annual rates of structural changes in the regions of Ukraine during 20112018*

\begin{tabular}{|c|c|c|c|c|c|c|}
\hline Regions & $\begin{array}{l}\text { Agriculture, } \\
\text { forestry and } \\
\text { fisheries }\end{array}$ & Industry & Construction & $\begin{array}{l}\text { Wholesale and retail } \\
\text { trade and repair of } \\
\text { motor vehicles and } \\
\text { motorcycles }\end{array}$ & $\begin{array}{c}\text { Transport, } \\
\text { warehousing, } \\
\text { postal and courier } \\
\text { activities }\end{array}$ & $\begin{array}{c}\text { Financial } \\
\text { activity }\end{array}$ \\
\hline Ukraine & 0,1473 & 0,0921 & 0,0824 & 0,1447 & 0,1293 & 0,1202 \\
\hline Vinnytsia & 0,1446 & 0,0875 & 0,0655 & 0,1273 & 0,0954 & 0,0938 \\
\hline Volyn & 0,1199 & 0,0963 & 0,0508 & 0,1067 & 0,1200 & 0,1439 \\
\hline Donetsk & 0,0742 & 0,0692 & 0,0293 & 0,0611 & 0,0827 & 0,0587 \\
\hline Dnipropetrovsk & 0,1429 & 0,1153 & 0,0819 & 0,2463 & 0,1294 & 0,0679 \\
\hline Zhytomyr & 0,1328 & 0,1054 & 0,0644 & 0,1077 & 0,0931 & 0,1458 \\
\hline Zakarpattia & 0,1167 & 0,0951 & 0,0637 & 0,1265 & 0,1031 & 0,1250 \\
\hline Zaporizhzhia & 0,1943 & 0,0973 & 0,0648 & 0,1860 & 0,1250 & 0,0536 \\
\hline Ivano-Frankivsk & 0,1197 & 0,0932 & 0,1512 & 0,1791 & 0,0780 & 0,0638 \\
\hline Kyiv & 0,1118 & 0,0844 & 0,0854 & 0,2631 & 0,1380 & 0,0547 \\
\hline Kirovohrad & 0,1551 & 0,1073 & 0,0325 & 0,1602 & 0,0931 & 0,0787 \\
\hline Luhansk & 0,0414 & 0,0642 & 0,0382 & 0,0607 & 0,0554 & 0,0668 \\
\hline Lviv & 0,0927 & 0,0972 & 0,0637 & 0,1912 & 0,1209 & 0,1186 \\
\hline Mykolaiv & 0,2018 & 0,0961 & 0,0372 & 0,1133 & 0,1219 & 0,0625 \\
\hline Odesa & 0,1516 & 0,0916 & 0,0840 & 0,1809 & 0,1046 & 0,0697 \\
\hline Poltava & 0,1910 & 0,1075 & 0,0772 & 0,1042 & 0,1280 & 0,0948 \\
\hline Rivne & 0,1342 & 0,1003 & 0,0732 & 0,1040 & 0,1132 & 0,1023 \\
\hline Sumy & 0,1537 & 0,0776 & 0,0500 & 0,3561 & 0,1057 & 0,1776 \\
\hline Ternopil & 0,1393 & 0,0872 & 0,0597 & 0,1135 & 0,0946 & 0,1576 \\
\hline Kharkiv & 0,1774 & 0,1012 & 0,0689 & 0,1670 & 0,1271 & 0,0462 \\
\hline Kherson & 0,1679 & 0,0868 & 0,0515 & 0,1044 & 0,0909 & 0,1302 \\
\hline Khmelnytskyi & 0,1662 & 0,0515 & 0,0598 & 0,1174 & 0,0824 & 0,1302 \\
\hline Cherkasy & 0,1423 & 0,0988 & 0,0469 & 0,1108 & 0,1151 & 0,1200 \\
\hline Chernivtsi & 0,1283 & 0,0698 & 0,0728 & 0,0941 & 0,1081 & 0,1098 \\
\hline Chernihiv & 0,1451 & 0,0976 & 0,0375 & 0,1367 & 0,0879 & 0,0903 \\
\hline city of Kyiv & 0,0000 & 0,0747 & 0,0995 & 0,1079 & 0,1404 & 0,2579 \\
\hline
\end{tabular}

* (excluding the temporarily occupied territory of the Autonomous Republic of Crimea, the city of Sevastopol and part of the anti-terrorist operation zone)

Table 2. Average annual rates of structural changes in the regions of Ukraine during 20112018 (continued)*

\begin{tabular}{|l|c|c|c|c|c|c|}
\hline Regions & $\begin{array}{c}\text { Real estate } \\
\text { transactions }\end{array}$ & $\begin{array}{c}\text { Public } \\
\text { adminstra- } \\
\text { tion }\end{array}$ & Education & $\begin{array}{c}\text { Health care } \\
\text { and social } \\
\text { assistance }\end{array}$ & $\begin{array}{c}\text { Provision of utilities } \\
\text { and individual services; } \\
\text { activities in the field of } \\
\text { culture and sports }\end{array}$ & $\begin{array}{c}\text { Arithmetic } \\
\text { mean value }\end{array}$ \\
\hline Ukraine & 0,1938 & 0,1273 & 0,1412 & 0,1354 & 0,1250 & 0,1308 \\
\hline Vinnytsia & 0,2880 & 0,1412 & 0,1441 & 0,1327 & 0,1328 & 0,1321 \\
\hline Volyn & 0,3197 & 0,1379 & 0,1610 & 0,1310 & 0,1389 & 0,1387 \\
\hline Donetsk & 0,0578 & 0,0771 & 0,1128 & 0,1274 & 0,0835 & 0,0758 \\
\hline Dnipropetrovsk & 0,1250 & 0,1379 & 0,1344 & 0,1293 & 0,0917 & 0,1274 \\
\hline Zhytomyr & 0,2972 & 0,1443 & 0,1358 & 0,1276 & 0,1080 & 0,1329 \\
\hline
\end{tabular}




\begin{tabular}{|l|c|c|c|c|c|c|}
\hline Regions & $\begin{array}{c}\text { Real estate } \\
\text { transactions }\end{array}$ & $\begin{array}{c}\text { Public } \\
\text { adminstra- } \\
\text { tion }\end{array}$ & Education & $\begin{array}{c}\text { Health care } \\
\text { and social } \\
\text { assistance }\end{array}$ & $\begin{array}{c}\text { Provision of utilities } \\
\text { and individual services; } \\
\text { activities in the field of } \\
\text { culture and sports }\end{array}$ & $\begin{array}{c}\text { Arithmetic } \\
\text { mean value }\end{array}$ \\
\hline Zakarpattia & 0,3244 & 0,1461 & 0,1595 & 0,1536 & 0,1141 & 0,1389 \\
\hline Zaporizhzhia & 0,2069 & 0,1757 & 0,1603 & 0,1667 & 0,1406 & 0,1428 \\
\hline Ivano-Frankivsk & 0,3750 & 0,1641 & 0,1250 & 0,1429 & 0,1417 & 0,1485 \\
\hline Kyiv & 0,2654 & 0,0825 & 0,1082 & 0,1107 & 0,0921 & 0,1269 \\
\hline Kirovohrad & 0,2222 & 0,1286 & 0,1213 & 0,1250 & 0,1250 & 0,1226 \\
\hline Luhansk & 0,0149 & 0,0663 & 0,1035 & 0,1071 & 0,0606 & 0,0617 \\
\hline Lviv & 0,2007 & 0,1287 & 0,1417 & 0,1182 & 0,1033 & 0,1252 \\
\hline Mykolaiv & 0,2049 & 0,1462 & 0,1473 & 0,1287 & 0,1500 & 0,1282 \\
\hline Odesa & 0,1898 & 0,1373 & 0,1545 & 0,1389 & 0,1250 & 0,1298 \\
\hline Poltava & 0,2721 & 0,1410 & 0,1313 & 0,1343 & 0,1161 & 0,1361 \\
\hline Rivne & 0,3109 & 0,1645 & 0,1426 & 0,1625 & 0,1471 & 0,1413 \\
\hline Sumy & 0,2130 & 0,1342 & 0,1379 & 0,1351 & 0,1184 & 0,1508 \\
\hline Ternopil & 0,3783 & 0,1360 & 0,1276 & 0,1352 & 0,1369 & 0,1423 \\
\hline Kharkiv & 0,1760 & 0,1225 & 0,1761 & 0,1500 & 0,1447 & 0,1325 \\
\hline Kherson & 0,2344 & 0,1354 & 0,1397 & 0,1250 & 0,1250 & 0,1265 \\
\hline Khmelnytskyi & 0,3028 & 0,1408 & 0,1632 & 0,1424 & 0,1071 & 0,1331 \\
\hline Cherkasy & 0,2263 & 0,1293 & 0,1360 & 0,1250 & 0,1071 & 0,1234 \\
\hline Chernivtsi & 0,3302 & 0,1731 & 0,1432 & 0,1611 & 0,1591 & 0,1409 \\
\hline Chernihiv & 0,3052 & 0,1461 & 0,1439 & 0,1250 & 0,1375 & 0,1321 \\
\hline city of Kyiv & 0,1545 & 0,0714 & 0,1219 & 0,1211 & 0,1081 & 0,1143 \\
\hline
\end{tabular}

* (excluding the temporarily occupied territory of the Autonomous Republic of Crimea, the city of Sevastopol and part of the anti-terrorist operation zone)

In general, the average annual rate of structural changes in 16 regions of Ukraine was higher than the average Ukrainian indicator (Table 2). The differentiation between high and low average annual rates of structural changes in the regions of Ukraine is 1.8. The average annual rate of structural changes in the economy of the regions grew due to such types of economic activity as: real estate transactions, rental, engineering and the provision of services to entrepreneurs, trade and agriculture. The lowest rates during 2011-2018 were structural changes in industry and construction (Fig. 2).

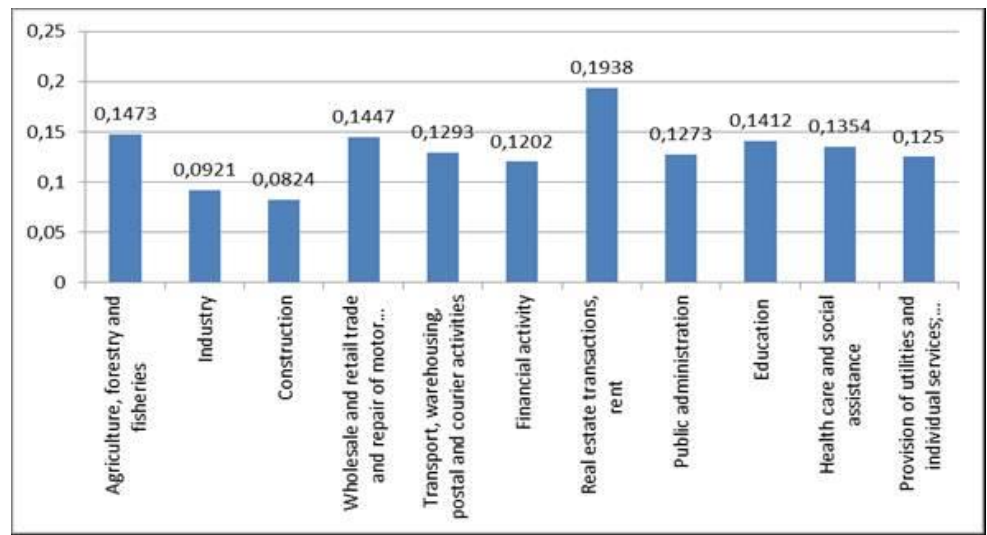

Figure 2. The average regional rate of structural changes in the economy of Ukraine (by type of economic activity) for the period 2011-2018. * (excluding the temporarily occupied territory of the Autonomous Republic of Crimea, the city of Sevastopol and part of the anti-terrorist operation zone) 
The data in Table 2 indicate that a significant impact on the average annual rate of structural changes in the Sumy region is due to the growth in the structure of the economy of the share of wholesale and retail trade; repair of motor vehicles; temporary accommodation and catering; financial activities and real estate transactions; Volyn and Zakarpattia regions - financial activities and real estate transactions; Ivano-Frankivsk, Ternopil and Kyiv regions - real estate transactions; Lviv and Dnipropetrovsk - trade, etc. At the same time, it should be noted that in no region of Ukraine did industry and construction have a tangible effect on the increase in the average annual rate of structural changes in the economy. The educational sphere had a significant impact on the pace of average annual structural changes in Volyn, Zaporizhzhia, Kharkiv regions, and the smallest in Kyiv region.

The rate of structural change reflects the change in the mass of the structural change per unit time and is calculated as the ratio of the mass of the structural change to the period of time over which they occurred. The rate of structural changes is calculated by the formula:

$$
V=\frac{\left(P_{1}-P_{0}\right)}{T}=\frac{M}{T}
$$

The assessment of structural changes in terms of their speed confirms that structural changes in the economy of Ukraine are quite slow.

During 2011-2018 in Ukraine as a whole, the fastest positive structural changes occurred in some areas of the service sector, namely real estate and trade. Thus, during 2011-2018, the rate of structural changes in the field of real estate transactions was 0.55 per year. A positive dynamics of the speed of structural changes in the industry is characteristic of all regions of Ukraine without exception. The most intensive changes in this area took place in Volyn region (1.01), and the least intensive in Kirovohrad region (0.44). The differentiation between these indicators is 2.3 times (Table 3).

Table 3. The speed of structural changes in the regions of Ukraine during 2011-2018*

\begin{tabular}{|l|c|c|c|c|c|c|}
\hline Regions & $\begin{array}{c}\text { Agriculture, } \\
\text { forestry and } \\
\text { fisheries }\end{array}$ & Industry & Construction & $\begin{array}{c}\text { Wholesale and retail } \\
\text { trade and repair of } \\
\text { motor vehicles and } \\
\text { motorcycles }\end{array}$ & $\begin{array}{c}\text { Transport, } \\
\text { warehousing, } \\
\text { postal and courier } \\
\text { activities }\end{array}$ & $\begin{array}{c}\text { Financial } \\
\text { activity }\end{array}$ \\
\hline Ukraine & 0,1875 & $-1,0125$ & $-0,1875$ & 0,3 & 0,05 & $-0,025$ \\
\hline Vinnytsia & 0,4375 & $-0,9$ & $-0,25$ & 0,025 & $-0,2875$ & $-0,0875$ \\
\hline Volyn & $-0,0875$ & $-0,5375$ & $-0,4375$ & $-0,3625$ & $-0,05$ & 0,0625 \\
\hline Donetsk & 0,0625 & $-1,875$ & $-0,1125$ & 0,4875 & 0,45 & $-0,25$ \\
\hline Dnipropetrovsk & 0,1 & $-0,475$ & $-0,125$ & 0,825 & 0,0375 & $-0,4$ \\
\hline Zhytomyr & 0,1375 & $-0,4875$ & $-0,2$ & $-0,225$ & $-0,3$ & 0,05 \\
\hline Zakarpattia & $-0,125$ & $-0,6875$ & $-0,325$ & 0,025 & $-0,25$ & 0 \\
\hline Zaporizhzhia & 0,5125 & $-1,3625$ & $-0,1625$ & 0,525 & $-0,475$ & $-0,2875$ \\
\hline Ivano-Frankivsk & $-0,0625$ & $-1,1375$ & 0,1625 & 0,6 & 0,15 & $-0,225$ \\
\hline Kyiv & $-0,2$ & $-1,1125$ & $-0,2375$ & 1,45 & $-0,4375$ & $-0,125$ \\
\hline Kirovohrad & 0,6625 & $-0,4125$ & $-0,4625$ & 0,3375 & 0,2125 & $-0,1375$ \\
\hline Luhansk & 0,1 & $-1,6375$ & $-0,0875$ & 0,6125 & $-0,0625$ & $-0,025$ \\
\hline Lviv & $-0,375$ & $-0,6375$ & $-0,3125$ & 0,775 & $-0,0375$ & $-0,25$ \\
\hline Mykolaiv & 0,9375 & $-0,85$ & $-0,4125$ & $-0,175$ & $-0,5375$ & $-0,3375$ \\
\hline Odesa & 0,2125 & $-0,525$ & $-0,275$ & 0,6375 & & \\
\hline
\end{tabular}




\begin{tabular}{|l|c|c|c|c|c|c|}
\hline Regions & $\begin{array}{c}\text { Agriculture, } \\
\text { forestry and } \\
\text { fisheries }\end{array}$ & Industry & Construction & $\begin{array}{c}\text { Wholesale and retail } \\
\text { trade and repair of } \\
\text { motor vehicles and } \\
\text { motorcycles }\end{array}$ & $\begin{array}{c}\text { Transport, } \\
\text { warehousing, } \\
\text { postal and courier } \\
\text { activities }\end{array}$ & $\begin{array}{c}\text { Financial } \\
\text { activity }\end{array}$ \\
\hline Poltava & 0,7 & $-0,8625$ & $-0,1625$ & $-0,2125$ & 0,025 & $-0,0875$ \\
\hline Rivne & 0,15 & $-0,7125$ & $-0,2125$ & $-0,3125$ & $-0,1125$ & $-0,075$ \\
\hline Sumy & 0,425 & $-1,9625$ & $-0,2625$ & 1,225 & $-0,1625$ & 0,1 \\
\hline Ternopil & 0,3 & $-0,7$ & $-0,2875$ & $-0,175$ & $-0,35$ & 0,075 \\
\hline Kharkiv & 0,3875 & $-0,625$ & $-0,275$ & 0,4625 & 0,025 & $-0,9375$ \\
\hline Kherson & 0,8625 & $-0,775$ & $-0,25$ & $-0,3125$ & $-0,3375$ & 0,0125 \\
\hline Khmelnytskyi & 0,725 & $-3,0875$ & $-0,3$ & $-0,0875$ & $-0,4$ & 0,0125 \\
\hline Cherkasy & 0,3625 & $-0,7125$ & $-0,4375$ & $-0,2$ & $-0,0875$ & $-0,0125$ \\
\hline Chernivtsi & 0,0625 & $-0,85$ & $-0,35$ & $-0,5375$ & $-0,15$ & $-0,05$ \\
\hline Chernihiv & 0,375 & $-0,75$ & $-0,35$ & 0,125 & $-0,375$ & $-0,125$ \\
\hline city of Kyiv & 0 & $-0,4875$ & $-0,125$ & $-0,5375$ & 0,2375 & 0,8375 \\
\hline
\end{tabular}

* (excluding the temporarily occupied territory of the Autonomous Republic of Crimea, the city of Sevastopol and part of the anti-terrorist operation zone)

Table 3. The speed of structural changes in the regions of Ukraine during 2011-2018 (continued)*

\begin{tabular}{|c|c|c|c|c|c|}
\hline Regions & $\begin{array}{l}\text { Real estate } \\
\text { transactions }\end{array}$ & $\begin{array}{c}\text { Public } \\
\text { adminstration }\end{array}$ & Education & $\begin{array}{l}\text { Health care and } \\
\text { social assistance }\end{array}$ & $\begin{array}{c}\text { Provision of utilities and } \\
\text { individual services; activities in } \\
\text { the field of culture and sports }\end{array}$ \\
\hline Ukraine & 0,55 & 0,0125 & 0,0875 & 0,0375 & 0 \\
\hline Vinnytsia & 0,75 & 0,125 & 0,1375 & 0,0375 & 0,0125 \\
\hline Volyn & 1,0125 & 0,0875 & 0,2625 & 0,025 & 0,025 \\
\hline Donetsk & 0,4375 & 0,125 & 0,1 & 0,0875 & 0,05 \\
\hline Dnipropetrovsk & 0 & 0,0375 & 0,0375 & 0,0125 & $-0,05$ \\
\hline Zhytomyr & 0,775 & 0,1875 & 0,0875 & 0,0125 & $-0,0375$ \\
\hline Zakarpattia & 0,8375 & 0,15 & 0,2625 & 0,1375 & $-0,025$ \\
\hline Zaporizhzhia & 0,475 & 0,1875 & 0,1625 & 0,1375 & 0,025 \\
\hline Ivano-Frankivsk & 0,925 & 0,1875 & 0 & 0,0625 & 0,025 \\
\hline Kyiv & 0,8 & $-0,425$ & $-0,0875$ & $-0,05$ & $-0,0625$ \\
\hline Kirovohrad & 0,4375 & 0,025 & $-0,025$ & 0 & 0 \\
\hline Luhansk & 0,3125 & 0,15 & 0,2375 & 0,1125 & 0,025 \\
\hline Lviv & 0,575 & 0,025 & 0,125 & $-0,0375$ & $-0,05$ \\
\hline Mykolaiv & 0,4875 & 0,125 & 0,125 & 0,0125 & 0,0375 \\
\hline Odesa & 0,5375 & 0,075 & 0,1625 & 0,05 & 0 \\
\hline Poltava & 0,5 & 0,0625 & 0,025 & 0,025 & $-0,0125$ \\
\hline Rivne & 0,725 & 0,225 & 0,1375 & 0,15 & 0,0375 \\
\hline Sumy & 0,475 & 0,0625 & 0,0875 & 0,0375 & $-0,0125$ \\
\hline Ternopil & 0,9625 & 0,075 & 0,025 & 0,05 & 0,025 \\
\hline Kharkiv & 0,525 & $-0,0125$ & 0,3375 & 0,075 & 0,0375 \\
\hline Kherson & 0,6125 & 0,075 & 0,125 & 0 & 0 \\
\hline Khmelnytskyi & 0,8 & 0,125 & 0,325 & 0,075 & $-0,0375$ \\
\hline Cherkasy & 0,5875 & 0,025 & 0,075 & 0 & $-0,0375$ \\
\hline Chernivtsi & 1,0875 & 0,375 & 0,175 & 0,1625 & 0,075 \\
\hline \begin{tabular}{|l|} 
Chernihiv \\
\end{tabular} & 0,775 & 0,175 & 0,125 & 0 & 0,025 \\
\hline city of Kyiv & 0,4625 & $-0,3$ & $-0,0125$ & $-0,0125$ & $-0,0625$ \\
\hline
\end{tabular}

* (excluding the temporarily occupied territory of the Autonomous Republic of Crimea, the city of Sevastopol and part of the anti-terrorist operation zone) 
The rate of positive structural changes in trade was 0.3 per year. However, this trend is not typical for all regions of Ukraine. In 10 regions of Ukraine there was a decrease in the contribution of trade to the creation of GVA, namely in Volyn, Zhytomyr, Poltava, Rivne, Ternopil, Kherson, Khmelnytskyi, Chernivtsi regions and city of Kyiv. The most rapid decrease in trade was in Chernivtsi region and city of Kyiv, namely at a rate of 0.54 per year, while, for example, in Ternopil and Mykolaiv regions, this figure was 0.175 per year. In other regions of Ukraine, structural changes in the industry had a positive dynamics. Thus, the highest rate of structural changes was in Sumy $(1.22 \%)$ and Dnipropetrovsk (0.82) regions. The differentiation between max and min values of the positive dynamics of the rate of structural changes in trade was 49 times.

For the period of 2011-2018 in Ukraine as a whole, the average annual rate of structural changes in agriculture was 0.19 per year. An increase in the share of agriculture in GVA was observed in most regions of Ukraine, except for Volyn, Zakarpattia, Ivano-Frankivsk, Kyiv and Lviv regions. The greatest intensity of structural changes in terms of speed was observed in Mykolayiv (0.94) and Kherson (0.86) regions.

The speed of structural changes in the field of transport and communications and public administration is quite low and does not exceed 0.1 per year. The speed of structural changes in the education sector is also quite insignificant compared to other sectors of the economy and is 0.08 per year. However, it should be noted that not all regions are characterized by a positive trend in increasing the contribution of education to the creation of GVA. Thus, in Kyiv, Kirovohrad regions and the city of Kyiv, the speed of structural changes is characterized by a negative value, which is evidence of the declining role of this area in the economic system of these regions. The lack of positive dynamics of increasing the speed of structural changes in the education sector is the main obstacle to creating an innovation-oriented model of economic development and reorientation of the structure of the regional economy to the requirements of the post-industrial type.

Along with these tendencies during the period under review, Ukraine as a whole experienced losses in industry, construction and financial activities. Thus, during 20112018, the most intense in the structure of the economy were the loss of the share of industry in the GVA. The rate at which its share was decreasing was 1.01 per year. Losses by industry of its contribution to the creation of GVA are characteristic for all regions of Ukraine without exception. The highest indicators were in Donetsk (1.87), Luhansk (1.63), Zaporizhzhia (1.36), Ivano-Frankivsk (1.14), Sumy (1.96), Khmelnytskyi (3.1) regions. Quite high rates of loss of industrial share are also in Volyn (0.53), Zhytomyr (0.48), Zakarpattia (0.68), Lviv (0.64), Mykolaiv (0.85), Poltava (0.86), Rivne (0.71), Kherson (0.77), Cherkasy (0.71), Chernivtsi (0.85) and Chernihiv (0.75) regions.

During this time, construction sector losses occurred at a rate of 0.19 per year. The rate of negative dynamics in the loss of construction share in the GVA is typical for most regions of Ukraine, with the exception of Ivano-Frankivsk region. The greatest losses in the construction of a share in the GVA occurred in the Volyn, Kirovohrad, Mykolaiv and Cherkasy regions.

During 2011-2018, there was also a loss of the share of financial activities in the structure of GVA. The rate of negative structural dynamics was 0.02 per year. This trend is typical for most regions of Ukraine, except for 8, namely Volyn, Zhytomyr, Zakarpattia, Sumy, Ternopil, Kherson, Khmelnytskyi regions and the city of Kyiv. The most intensive is the 
rate of decline of the financial sector in GVA in the Kharkiv region (0.94 per year). It was also quite high in Ivano-Frankivsk and Odesa regions and amounted to 0.29 and 0.24 per year, respectively. Estimation of the intensity of structural shifts in terms of their speed once again confirms the slow pace of these processes in the economy of Ukraine.

Closely related to the concept of mass and rate of structural changes in the economy is the indicator of their intensity $(\mathrm{E})$. In general, it is calculated by the formula:

$E=M \times V$

where $\mathrm{M}$ is the mass of structural change;

$\mathrm{V}$ is the speed of structural change.

The more intense the structural changes, the greater the structural role they will play in the economy. During the study period, the coefficient of intensity of structural changes in the economy of Ukraine was 0.245. This only confirms the absence of radical structural changes in the economy (Fig. 3).

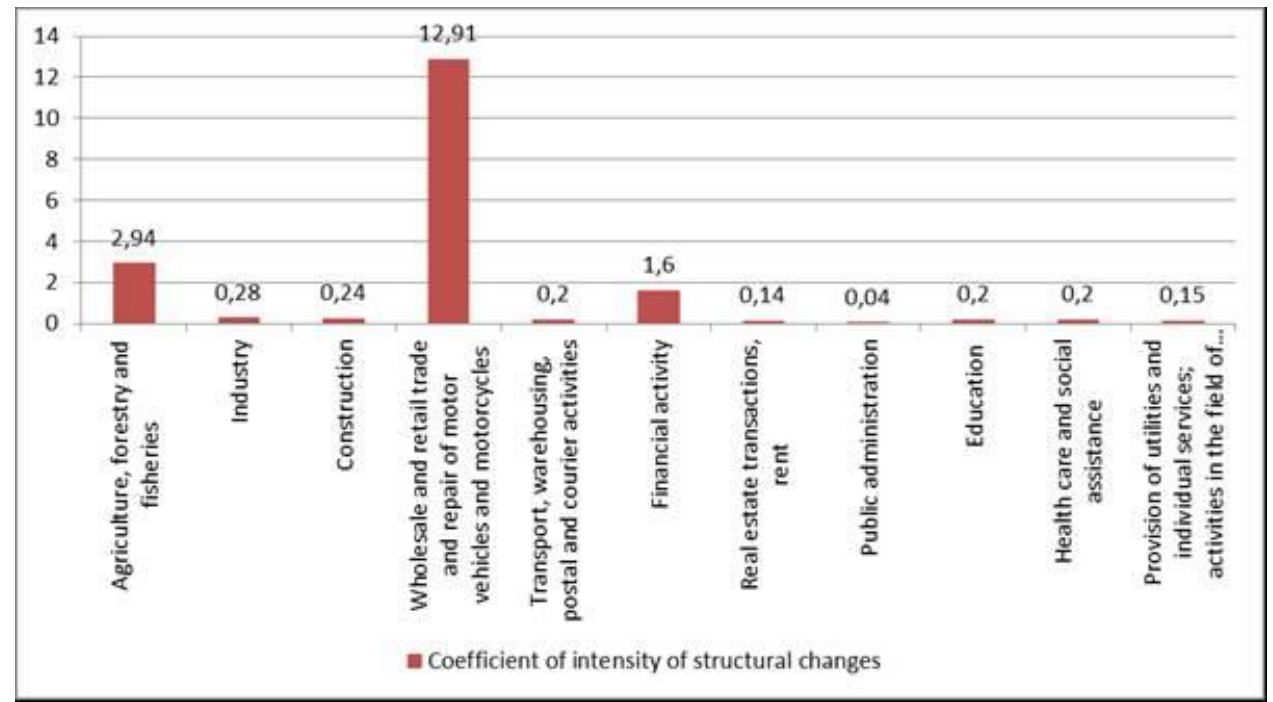

Figure 3. The intensity of structural changes in the economy of Ukraine during 2011-2018. * (excluding the temporarily occupied territory of the Autonomous Republic of Crimea, the city of Sevastopol and part of the antiterrorist operation zone)

The most intensive structural changes took place in wholesale and retail trade; repair of motor vehicles and motorcycles, where this indicator was 12.91, financial and insurance activities (1.6) and agriculture (2.94). The rate of intensity of structural changes was rather low in industry and, in particular, mining -0.04 , which suffered the greatest losses due to hostilities in the Donetsk and Luhansk regions.

It is possible to quantify the dynamics and scale of structural changes based on the integral coefficient of structural changes. This coefficient is calculated by the formula:

$K_{\mathrm{iHT}}=\sqrt{\frac{\sum_{i=1}^{T}\left(P_{1}-P_{0}\right)^{2}}{\sum_{i=1}^{T} P^{2}{ }_{1}+\sum_{i=1}^{T} P^{2}{ }_{0}}}$.

The value of the integral coefficient of structural shifts varies from 0 to 1 or from 0 to 
$100 \%$. The ratio will be closer to 0.01 or $1.00 \%$ when the difference between comparable structures is the smallest. The more intense the structural changes, the more structureforming role they play in the economy, and the coefficient will be closer to 1.00 or $100 \%$. During 2011-2018, as a whole in the Ukrainian economy, the coefficient of the intensity of structural changes was 0.182 , which is evidence of the absence of rapid and cardinal structural changes in the economy.

\section{Conclusions}

The results of the analysis of changes in the economy of the regions of Ukraine indicate the preservation of their traditional structure. During 2011-2018, structural changes in the economy are characterized by a general pattern: sectors that provide a significant share in the creation of GVA over time are more stable than others. This is evidenced by the relative stability of the share of such large sectors as industry, agriculture and services, despite the significant dynamics of their changes over time, while the share of education and health care, despite the dynamics of its growth, continues to make a relatively small contribution to creation of GVA. Structural changes in the economy of the country's regions, which would meet the priorities of the model of sustainable economic growth, require significant investment and a long time, as well as purposeful adaptation of the economy to the rational social and personal needs of the population.

The formation of the structure of the economy of the regions in terms of implementing the model of sustainable development today is influenced by the latest processes that take place in society, the main of which are the development of transnational corporations, dealerships, network business structures in production, trade and other areas of economic activity, the creation of clusters, technopolises, industrial parks, etc., the spread of innovative types of services, etc. These processes can change the traditional structure of the regional economies, but they can not solve all the problems associated with their structural modernization.

Thus, the study proves that the acceleration of the processes of structural modernization is possible under the conditions of formation of an innovative model of economic development of Ukraine and its regions. The structural priorities of this model are:

1) growth in the share of high-tech manufacturing, telecommunications, financial and business services, as well as socially oriented economic activities;

2) ecological restructuring and modernization of production capacities of basic branches of the economy in order to reduce the resource intensity of production and increase its energy consumption through the introduction of alternative energy sources and energysaving technologies;

3) achieving a rational ratio of proportions between the public and market sectors;

4) ensuring the priority of accumulation over consumption, overcoming territorial disproportion.

The practical value of this research is to stimulate structural changes in the economy of Ukraine and its regions according to these priorities. Prospects for further research are aimed at developing priority ways for sustainable development of the country to ensure the necessary structural changes. 


\section{References}

Almeida, L. M. D. L., \& Balanco, P. A. D. F. (2020). Application of multivariate analysis as complementary instrument in studies about structural changes: An example of the multipliers in the US economy. Structural Change and Economic Dynamics, 53, 189-207. doi:10.1016/j. strueco.2020.02.006

Andrusiv, U. \& Galtsova, O. (2017). Evaluation of innovation activity of construction enterprises. Scientific bulletin of Polissia, 3(11), P.1, 204- 215 doi:10.25140/2410-9576-2017-1-3(11)-204-215

Andrusiv, U., Simkiv, L., Dovgal, O., Demchuk, N., Potryvaieva, N., Cherchata, A., Popadynets, I., Tkachenko, G., Serhieieva, O \& Sydor, H. (2020). Analysis of economic development of Ukraine regions based on taxonomy method. Management Science Letters , 10(3), 515-522. doi: 10.5267/j.msl.2019.9.029

Benner, M. (2019). Smart specialization and institutional context: the role of institutional discovery, change and Leapfrogging. European Planning Studies, 27 (9), pp. 1791-1810. doi: 10.1080/09654313.2019.1643826

Bogachkova, L. Y., Zaytseva, Y. V., \& Usacheva, N. Y. (2019). The structural changes impact estimation while monitoring the performance of energy efficiency policy at subregional level. doi:10.1007/978-3-030-18553-4_19

Cravino, J., \& Sotelo, S. (2019). Trade-induced structural change and the skill premium. American Economic Journal: Macroeconomics, 11(3), 289-326. doi:10.1257/mac.20170434

D’Adda, D., Guzzini, E., Iacobucci, D., Palloni, R. (2019). Is Smart Specialisation Strategy coherent with regional innovative capabilities? Regional Studies, 53 (7), pp. 1004-1016. doi: 10.1080/00343404.2018.1523542

Dyatlov, S. A., Haykin, M. M., \& Lobanov, O. S. (2019). The regulatory institutions for the neural network economy. Paper presented at the Innovation-Based Development of the Mineral Resources Sector: Challenges and Prospects - 11th Conference of the Russian-German Raw Materials, 2018, 499-506

Gnangnon, S. K. (2020). Comparative advantage following (CAF) development strategy, aid for trade flows and structural change in production. Journal of Economic Structures, 9(1) doi: 10.1186/s40008-0200177-8

Gross regional product in 2016. Statistical collection. Kyiv: State Statistics Service of Ukraine, 2018. 141 p.

Gross regional product: Statistical collection. Kyiv: State Statistics Service of Ukraine, 2014. 79 p.

Herrendorf, B., Rogerson, R., \& Valentinyi, T. (2014). Growth and structural transformation doi: 10. 1016/B978-0-444-53540-5.00006-9

Ievdokymov, V., Lehenchuk, S., Zakharov, D., Andrusiv, U., Usatenko, O \& Kovalenko, L. (2020). Social capital measurement based on "The value explorer" method. Management Science Letters, 10(6), 1161 1168. doi: $10.5267 /$ i.msl.2019.12.002

Ikpe, E. (2018). The enduring relevance of the developmental state paradigm across space and time: Lessons for africa on structural transformation and agriculture in oil-rich contexts. Journal of Asian and African Studies, 53(5), 764-781. doi:10.1177/0021909617722375

Ivashkiv, I., Kupalova, H., Goncharenko, N., Andrusiv, U., Streimikis, J., Lyashenko, O., . . Saukh, I. (2020). Environmental responsibility as a prerequisite for sustainable development of agricultural enterprises. Management Science Letters, 10(13), 2973-2984. doi:10.5267/j.msl.2020.5.028

Khan, M. A. (2020). Cross sectoral linkages to explain structural transformation in nepal. Structural Change and Economic Dynamics, 52, 221-235. doi:10.1016/j.strueco.2019.11.005

Kneysler, O., Andrusiv, U., Spasiv, N., Marynchak, L. \& Kryvytska, O. (2020). Construction of economic models of ensuring Ukraine's energy resources economy.10th International Conference on Advanced Computer Information Technologies (ACIT 2020), Conference Proceedings, Deggendorf, Germany September $16-18,651-656$.

Kramarenko, I., Irtyshcheva, I., Shults, S., Stehnei, M., Kateryna, B., Boiko, Y., . . Hryshyna, N. (2020). An economic management system for sustainable development in black sea region. Accounting, 6(4), 387394. doi: $10.5267 /$ j.ac.2020.5.003

Kroll, H. (2019). Eye to eye with the innovation paradox: why smart specialization is no simple solution to policy design (2019) European Planning Studies, 27 (5), pp. 932-951. doi: 10.1080/09654313.2019.1577363

Official site of the State Statistics Service of Ukraine. URL: http: //www.ukrstat.gov.ua (access date: 05.03.2020).

Popadynets I., Andrusiv U., Shtohryn M \& Galtsova O. 2020. The effect of cooperation between universities and stakeholders: Evidence from Ukraine. International Journal of Data and Network Science, 4(2), 199-212. doi: $10.5267 /$ j.ijdns.2020.1.001. 
Rohozian, Y., Zablodska, I., Tatarchenko, O., Zavoyskih, Y., \& Korsakova, O. (2017). Assessment process of economic expediency for the interregional cooperation: Ukrainian-Polish content. International Journal of Economic Research, 14(16), 375-386.

Rohozian, Y., Hrechana, S., Kuzmenko, O., Derzhak, N., Kuchmenko, V., \& Plietnov, M. (2020). Sustainable development management of local territories in the eastern ukraine in conditions of military conflict: Identification criteria. European Journal of Sustainable Development, 9(3), 425-442. doi:10.14207/ejsd.2020.v9n3p425

Saleem, H., Shahzad, M., Khan, M. B., \& Khilji, B. A. (2019). Innovation, total factor productivity and economic growth in pakistan: A policy perspective. Journal of Economic Structures, 8(1). doi:10.1186/s40008-019-0134-6

Sotarauta, M. (2018). Smart specialization and place leadership: Dreaming about shared visions, falling into policy traps? Regional Studies, Regional Science, 5 (1), pp. 190-203. doi: 10.1080/21681376.2018.1480902

Treshchevsky, Y. I., Voronin, V. P., Tabachnikova, M. B., \& Franovskaya, G. N.(2018). Economic and statistical analysis in evaluating the perspectives of structural changes of regions' economy. doi:10.1007/978-3-319-75383-6_66

Yadav, A. K., \& Joseph, J. (2018). Growth and structural changes in indian economy-an analysis. Reflecting on india's development: Employment, skill and health (pp. 45-65) doi:10.1007/978-981-13-1414-8_3

Zablodska, I., Akhromkin, Y., Akhromkin, A., Bielousova, L., \& Litvinova, I. (2020). World experience in public administration of the transformation of energy-dependent regions in the context of their sustainable development. [Światowe doświadczenie w administracji publicznej i transformacji regionów zależnych od energii w kontekście ich zrównoważonego rozwoju]. Problemy Ekorozwoju, 15(2), 235-244.

Zhao, S. X., Chan, Y., \& Berjano, C. B. R. (2012). Industrial structural changes in hong kong, China under one country, two systems framework. Chinese Geographical Science, 22(3), 302-318. doi:10.1007/s11769012-0537-x 